\title{
The Career Planning Attitudes of Young Individuals: The Case of Department of Sports Management at IU-Cerrahpaşa Sports Sciences Faculty
}

\author{
Yesim Avunduk \\ Faculty of Economic, Administrative and Social Sciences, Ayvansaray University \\ Ayvansaray Cd. No:45 D:45, 34662 Fatih, İstanbul, Turkey \\ Tel: 90-212-444-7696Ｅ-mail: yesimavunduk@gmail.com \\ Alpaslan Baki Ertekin (Corresponding author) \\ Faculty of Sport Sciences, Istanbul Gelisim University \\ Cihangir M. Sht. Jand. Kom. Er Hakan Öner Sk. No:1 Avcılar, İstanbul, Turkey \\ Tel: 90-212-422-7000Ｅ-mail: abe.akademik@gmail.com
}

Received: October 21, 2020 Accepted: November 19, 2020

Published: November 30, 2020

doi:10.5296/jei.v6i2.17878 URL: https://doi.org/10.5296/jei.v6i2.17878

\begin{abstract}
The study aimed to examine the career attitudes of young individuals by certain variables. The study sample consisted of 173 volunteer students, 105 (60.7\%) male and 68 (39.3\%) female, studying at the Department of Sports Management of Istanbul University-Cerrahpaşa Sports Sciences Faculty. In addition to a personal information form, the "Career Future Inventory (CFI)" developed by Rottinghaus, Day, and Borgen (2005) was used in the study. The validity and reliability study of the tool was conducted by Kalafat (2012). The CFI is a 5-point Likert type scale including 25 items and 3 sub-dimensions. To the Kolmogorov-Smirnov normality test results, the data did not have a normal distribution, so the Mann-Whitney U test was applied for the analysis of bivariate data, and the Kruskall Wallis test for more than two variables. Significant differences were found between CFI sub-dimensions by gender, grade level and academic grade point averages. It was concluded that career planning attitudes of young individuals varied by certain variables, and academic achievement affected career attitudes.
\end{abstract}


Keywords: Young individuals, Career, Career planning

\section{Introduction}

The "career" word can be defined as the path that a person follows to achieve success in the working life. Its roots date back to the French word "carriere" (Iș1k, 2017). Arık and Seyhan (2016) describe "career" as the high positions and the progress that a person achieved in business life. Career can also be characterized by occupation or profession that a person works in till the end of his working life. Thus, a person's career is more than just his occupation, it involves the education and expectations related to that career and the progress that occurs with the professional knowledge and experience in workplace (Atay, 2006).

Career planning is the pre-planning process of individuals for the desired occupations and positions who are not in business life or have not reached the positions they desire yet (Gökoğlan \& Kaval, 2020). According to Gezer (2010), career planning is the process of self-assessment, setting short-, medium- and long-term goals, making a plan considering those goals, and implementing them. Career planning involves the stages of making an overview, determining the sector, marketing plan, one's strengths and weaknesses, and making an action plan and finance plan (Taşliyan et al., 2011).

Fisher and Griggs (1995) emphasized the importance of the following factors for a career planning of students:

- Parental factors

- $\quad$ Friendship factors

- $\quad$ Teacher factors

- Gender role expectations

- Academic achievement

- Other factors such as death, alcohol abuse, and certain illnesses (as cited in Gıldı \& Ersoy Kart, 2017).

Career choice is one of the most critical decisions in life, and maybe that decision can be made once in a lifetime (Serin et al., 2014). In Turkey, individuals make those decisions before the university exam. Such decisions that can influence a person's whole life are made in an unplanned way and with the effect of several environmental factors (Özdemir, 2010). The studies in the literature revealed that in addition to the factors such as general knowledge, interest in the occupation, and the job satisfaction, the personal characteristics are also influential in determining an occupation and career for young individuals. Besides, the socio-economic status and family situations have distinctive effects on career choice (Y1lmaz et al., 2012). In this sense, this study aimed to examine the career planning attitudes of young people by certain variables. 


\section{MIMacrothink}

\section{Materials and Methods}

\subsection{Research Model}

The screening model is one of the quantitative research methods and describes the current situation. The topic of research (i.e., an event, a subject or an object) is defined within its conditions and as it is (Kuzu, 2013). A screening model was applied for the current study.

\subsection{Research Universe and Sample}

A research universe involves all individuals and elements that possess similar characteristics related to a study (Şimşek, 2012). The universe of the current study consisted of all the individuals studying at the sports management departments of higher education institutions in Turkey.

A study sample is a subset selected considering specific characteristics in the universe and it is thought to represent the universe (Şimşek, 2012). The sample of the current study included 173 volunteer students-105 (60.7\%) male, and $68(39.3 \%)$ female-studying at the Department of Sports Management at Istanbul University-Cerrahpaşa Sports Sciences Faculty.

\subsection{Data Collection Tools}

The personal information form was prepared by the researcher, and it included 5 questions about certain personal characteristics such as gender, age, grade level, academic grade point average, and welfare status.

"Career Future Inventory" (CFI) was developed by Rottinghaus, Day, and Borgen (2005), and the validity and reliability study was carried out by Kalafat (2012). It is a 5-point Likert type scale (1-Strongly Agree, 5-Strongly Disagree), including 25 items, and three sub-dimensions (career adaptability, career optimism, perceived knowledge). The internal consistency coefficient of the inventory was 0.88 .

\subsection{Data Analysis}

The study data were analyzed using the SPSS 20 package program. Besides, the percentage (\%) and frequency (f) methods were applied as statistical methods.

The Kolmogorov-Smirnov normality test was performed to determine whether the data obtained through an online Google Form had a normal distribution, and the results revealed it did not have a normal distribution. Therefore, the Mann Whitney U test was applied for the bivariate data, and the Kruskal Wallis test was performed for more than two variables. 


\section{Findings}

Table 1. Demographic characteristics

\begin{tabular}{|c|c|c|c|}
\hline & & f & $\%$ \\
\hline \multirow{3}{*}{ Gender } & Male & 105 & 60.7 \\
\hline & Female & 68 & 39.3 \\
\hline & Total & 173 & 100.0 \\
\hline \multirow{4}{*}{ Grade Level } & $2^{\text {nd }}$ grade & 58 & 33.5 \\
\hline & $3^{\text {rd }}$ grade & 64 & 37.0 \\
\hline & $4^{\text {th }}$ grade & 51 & 29.5 \\
\hline & Total & 173 & 100.0 \\
\hline \multirow{5}{*}{ Academic Grade Point Averages } & $2.00-2.50$ & 27 & 15.6 \\
\hline & $2.51-3.00$ & 58 & 33.5 \\
\hline & $3.01-3.50$ & 54 & 31.2 \\
\hline & $3.51-4.00$ & 34 & 19.7 \\
\hline & Total & 173 & 100.0 \\
\hline \multirow{4}{*}{ Age } & $18-21$ years & 44 & 25.4 \\
\hline & $22-25$ years & 89 & 51.4 \\
\hline & 26 years and older & 40 & 23.1 \\
\hline & Total & 173 & 100.0 \\
\hline \multirow{4}{*}{ Welfare Status } & High & 44 & 25.4 \\
\hline & Medium & 91 & 52.6 \\
\hline & Low & 38 & 22.0 \\
\hline & Total & 173 & 100.0 \\
\hline
\end{tabular}

Table 1 shows the demographic characteristics of the participants. As seen in the table, $60.7 \%$ of the participants were male, and $39.3 \%$ were female; $33.5 \%$ were in the 2 nd grade, $37 \%$ were in the $3 \mathrm{rd}$ grade, and $29.5 \%$ were in the 4 th grade. The academic grade point average of $15.6 \%$ ranged between $2.00-2.50 ; 33.5 \%$ were in the range of $2.51-3.00 ; 31.2 \%$ were in the range of $3.01-3.50$, and $19.7 \%$ in the range of $3.51-4.00$. It was found that $25.4 \%$ were between $18-21$ years old; $51.4 \%$ were between $22-25$ years old, and $23.1 \%$ were 26 years old 
and above. Of the participants, 25.4\% had a "high", 52.6\% had "medium", and 22\% had "low" welfare status.

Table 2. Analysis results between CFI sub-dimensions by gender

\begin{tabular}{|l|l|l|l|l|}
\hline & Male $(\mathbf{N}=\mathbf{1 0 5})$ & Female $(\mathbf{N}=\mathbf{6 8})$ & & \\
\hline CFI & Rank Avg. & Rank Avg. & $\mathbf{z}$ & $\mathbf{p}$ \\
\hline Career Adaptability & 92.26 & 78.88 & -1.717 & .086 \\
\hline Career Optimism & 91.09 & 80.68 & -1.336 & .182 \\
\hline Perceived Knowledge & 92.40 & 78.65 & -2.277 & $\mathbf{. 0 4 4} *$ \\
\hline
\end{tabular}

Table 2 presents the results of Mann Whitney-U test that was performed to determine whether there was a significant difference between CFI sub-dimensions by gender.

According to the analysis result, there was no statistically significant difference in the "Career Adaptability" ( $\mathrm{z}=-1.717, \mathrm{p}>0.05)$ and "Career Optimism" $(\mathrm{z}=-1.336, \mathrm{p}>0.05)$ sub-dimensions of CFI by gender. However, a statistically meaningful difference was seen in "Perceived Knowledge" sub-dimension by gender $(\mathrm{z}=-2.277, \mathrm{p}<0.05)$.

Table 3. Analysis results between CFI sub-dimensions by grade level

\begin{tabular}{|l|l|l|l|l|l|}
\hline & 2.Sınıf $(\mathbf{N}=\mathbf{5 8})$ & 3.Sinıf $(\mathbf{N}=\mathbf{6 4})$ & 4.Sınıf $(\mathbf{N}=\mathbf{5 1})$ & & \\
\hline CFI & Rank Avg. & Rank Avg. & Rank Avg. & $\mathbf{X}^{\mathbf{2}}$ & $\mathbf{p}$ \\
\hline Career Adaptability & 77.05 & 88.64 & 91.24 & 9.469 & $\mathbf{. 0 3 5 *}$ \\
\hline Career Optimism & 77.76 & 92.05 & 91.17 & 2.985 & .225 \\
\hline Perceived Knowledge & 83.34 & 90.57 & 86.69 & .657 & .720 \\
\hline
\end{tabular}

Table 3 demonstrates the results of the Kruskal-Wallis test which was carried out to find out whether there was a significant difference between CFI sub-dimensions by grade levels.

The analysis result revealed a statistically significant difference in the "Career Adaptability" sub-dimension by grade level $\left(X^{2}=9.469, \mathrm{p}<0.05\right)$. However, there was no significant difference in "Career Optimism" $\left(\mathrm{X}^{2}=2.985, \mathrm{p}>0.05\right)$ and "Perceived Knowledge" $\left(\mathrm{X}^{2}\right.$ $=.657, \mathrm{p}>0.05$ ) sub-dimensions by grade levels of the participants. 
Table 4. Analysis results between CFI sub-dimensions by academic grade point averages

\begin{tabular}{|c|c|c|c|c|c|c|}
\hline \multirow[t]{2}{*}{ CFI } & $\begin{array}{l}2.00-2.50 \\
(N=27)\end{array}$ & $\begin{array}{l}2.51-3.00 \\
(N=58)\end{array}$ & $\begin{array}{l}3.01-3.50 \\
(N=54)\end{array}$ & $\begin{array}{l}3.51-4.00 \\
(N=34)\end{array}$ & \multirow[t]{2}{*}{$X^{2}$} & \multirow[t]{2}{*}{$\mathbf{p}$} \\
\hline & \multicolumn{4}{|c|}{ Rank Avg. } & & \\
\hline Career Adaptability & 85.94 & 79.66 & 101.22 & 77.76 & 6.774 & .079 \\
\hline Career Optimism & 86.20 & 81.48 & 100.29 & 75.94 & 6.180 & .103 \\
\hline Perceived Knowledge & 82.94 & 76.73 & 105.56 & 78.25 & 11.404 & $.010 *$ \\
\hline
\end{tabular}

A Kruskall-Wallis test was performed to determine whether there was a significant difference between CFI sub-dimensions by academic grade averages, and the test results are given in Table 4 above.

According to the analysis results, there was no statistically significant difference in "Career Adaptability" $\left(X^{2}=6.774, p>0.05\right)$ and "Career Optimism" $\left(X^{2}=6.180, p>0.05\right)$ sub-dimensions by academic grade point averages of individuals. Nevertheless, s statistically significant difference was found in "Perceived Knowledge" sub-dimension by academic grade point averages $\left(\mathrm{X}^{2}=11.404, \mathrm{p}<0.05\right)$.

Table 5. Analysis results between CFI sub-dimensions by age

\begin{tabular}{|l|l|l|l|l|l|}
\hline \multirow{2}{*}{ CFI } & $\begin{array}{l}\mathbf{1 8 - 2 1} \text { years } \\
(\mathbf{N = 4 4 )}\end{array}$ & $\begin{array}{l}\mathbf{2 2 - 2 5} \text { years } \\
\mathbf{( N = 8 9 )}\end{array}$ & $\begin{array}{l}\text { 26 years and older } \\
(\mathbf{N}=\mathbf{4 0})\end{array}$ & $\mathbf{X}^{\mathbf{2}}$ & $\mathbf{p}$ \\
\cline { 2 - 7 } & Rank Avg. & & & \\
\hline Career Adaptability & 96.38 & 80.36 & 91.46 & 3.428 & .180 \\
\hline Career Optimism & 92.32 & 81.78 & 92.76 & 1.996 & .369 \\
\hline Perceived Knowledge & 93.63 & 81.80 & 91.29 & 2.084 & .353 \\
\hline
\end{tabular}

Table 5 shows the results of the Kruskall-Wallis test that determined whether there was a significant difference between CFI sub-dimensions by age.

According to the test results, no statistically significant difference was found in sub-dimensions of the CFI by age: "Career Adaptability" $\left(\mathrm{X}^{2}=3.428, \mathrm{p}>0.05\right)$, "Career Optimism" $\left(\mathrm{X}^{2}=1.996, \mathrm{p}>0.05\right)$, and "Perceived Knowledge" $\left(\mathrm{X}^{2}=2.084, \mathrm{p}>0.05\right)$. 
Table 6. Analysis results between CFI sub-dimensions by welfare status

\begin{tabular}{|l|l|l|l|l|l|}
\hline \multirow{2}{*}{ CFI } & High $(\mathbf{N}=\mathbf{4 4})$ & Medium $(\mathbf{N}=\mathbf{9 1})$ & Low $(\mathbf{N}=\mathbf{3 8})$ & \multirow{2}{*}{ X $^{\mathbf{2}}$} & \multirow{2}{*}{ p } \\
\cline { 2 - 7 } & \multicolumn{3}{|c|}{ Rank Avg. } \\
\hline Career Adaptability & 77.24 & 87.74 & 96.53 & 3.070 & .216 \\
\hline Career Optimism & 78.30 & 87.16 & 96.68 & 2.756 & .252 \\
\hline Perceived Knowledge & 85.76 & 84.47 & 94.49 & 1.141 & .565 \\
\hline
\end{tabular}

The Kruskall-Wallis test was performed to determine whether there was a significant difference between CFI sub-dimensions by welfare status of individuals, and the test results are shown in Table 6 above.

The analysis result revealed no difference by welfare status in the "Career Adaptability" $\left(\mathrm{X}^{2}\right.$ $=3.070, \mathrm{p}>0.05)$, "Career Optimism" $\left(\mathrm{X}^{2}=2.756, \mathrm{p}>0.05\right)$, and "Perceived Knowledge" $\left(\mathrm{X}^{2}=1.141, \mathrm{p}>0.05\right)$.

\section{Discussion and Conclusion}

The analysis test results revealed that there was no statistically significant difference in "career adaptability" and "career optimism" sub-dimensions by gender. However, a meaningful difference was found in the "perceived knowledge" sub-dimension. When the average scores were examined, it was seen that the average scores of males were higher than females. Hence, it can be inferred that male individuals have a better knowledge of the labour market than female individuals. Several studies in the literature emphasized significant differences in career attitudes of students by gender (Büyükyılmaz et al., 2016; Üzüm \& Uçkun, 2015; Kılıç et al., 2020; Coetzee \& Harry, 2015) although a few studies are indicating no difference by gender (Temel \& Nas, 2018; Özşen, 2019). Similarly, significant differences were found in favour of male participants in those studies, while some studies yielded differences in favour of female participants. The increasing number of working women can be a factor. Üzüm and Uçkun (2015) indicated that it might stem from recognizing the importance of economic freedom of women today.

There was no statistically significant difference in "career optimism" and "perceived knowledge" sub-dimensions by grade levels of the participant students, but a meaningful difference was observed in the "career adaptability" sub-dimension. The average scores of the 4 th graders were higher than the averages of students studying in the 2 nd and 3rd grade. It is an expected result, since, as Karadaş et al. (2017) stated, senior students generally have a better knowledge of career adaptability and the labour market. Although the scores of senior students in the "career adaptability" sub-dimension were high in the current study, no significant difference was found in the "perceived knowledge" about the labour market. Karadaş et al. (2017) also found no significant difference in career attitudes by grade levels. Career adaptability refers to following new developments and innovations in the sector and being prepared for possible changes in a career (Kalafat, 2012). Thus, it can be expressed that 
the 4 th-graders are more prepared than the lower-graders on condition of innovations and changes relates to the career plan.

Statistically, no difference was found in "career adaptability" and "career optimism" sub-dimensions by academic grade point averages of the participants, but a significant difference was observed in the "perceived knowledge" sub-dimension. In this sense, it was determined that most of the participants had an academic grade point average of 3.01 and above. Therefore, it can be indicated that the students who have high academic achievement have the disposition to possess better knowledge and experience of the employment trends in the sector, adaptation to changes in business life, and positive thinking in career planning.

There was no statistically significant difference in "career adaptability", "career optimism", and "perceived knowledge" sub-dimensions by age. Similarly, Büyükyılmaz et al. (2016), Temel and Nas (2018), and Kilıç et al. (2020) found no meaningful difference in career attitudes by age factor, which overlaps with the findings of the current study.

In terms of the welfare status of the participants, statistically significant no difference was observed in "career adaptability", "career optimism", and "perceived knowledge" sub-dimensions. Kılıç et al. (2020), Büyükyılmaz et al. (2016), and Üzüm and Uçkun (2015) revealed that monthly income did not influence career attitudes of students. Those results were in parallel with the current findings.

Ultimately, it has been concluded that certain variables affected the career planning attitudes of young people, and academic success was also played an important role in career attitudes.

\section{References}

Arık, N., \& Seyhan, B. (2016). Üniversite öğrencilerinin kariyer planlamasında teknoloji bilgisi ve gelecek beklentilerinin rolü. İnsan Ve Toplum Bilimleri Araştırmaları Dergisi, 5(7), 2218-2231. https://doi.org/10.15869/itobiad.260261

Atay, S. (2006). Kariyer yönetiminin örgütsel bağlllı̆̆a etkisi. Yüksek Lisans Tezi. Afyon Kocatepe Üniversitesi Sosyal Bilimler Enstitüsü İşletme Anabilim Dalı, Afyon.

Büyükyılmaz, O., Ercan, S., \& Gökerik, M. (2016). Öğrencilerin kariyer planlama tutumlarının demografik faktörler açısından değerlendirilmesi: Karabük üniversitesi işletme fakültesi öğrencileri üzerine bir araştırma. İnsan Ve Toplum Bilimleri Araştırmaları Dergisi, 5(7), 2065-2076.

Coetzee, M., \& Harry, N. (2015). Gender and hardiness as predictors of career adaptability: an exploratory study among black call centre agents. South African Journal of Psychology, 45(1), 81-92. https://doi.org/10.1177/0081246314546346

Fisher, T. A., \& Griggs, M. B. (1995), Factors that influence the career development of African-American and Latino youth. The Journal of Vocational Education Research, 20(2), $57-74$.

Gezer, M. (2010). Kariyer planlanmasında meslek seçiminin önemi: meslek lisesi son sinıf öğrencileri üzerine bir araştırma. Yüksek Lisans Tezi. Sakarya Üniversitesi Sosyal Bilimler 
Enstitüsü, Sakarya.

Gökoğlan, K., \& Kaval, U. (2020). öğrencilerin kariyer stratejileri üzerine bir araştırma: dicle üniversitesi örneği. Turkish Business Journal, 1(1), 15-28.

Güldü, Ö., \& Ersoy Kart, M. (2017). Kariyer planlama sürecinde kariyer engelleri ve kariyer geleceği algılarının rolü. Ankara Üniversitesi SBF Dergisi, 7(2), 377-400. https://doi.org/ 10.1501/SBFder_0000002450

Işık, M. (2017). Üniversite öğrencilerinin kariyer değerler algılarının karşılaştırılmasına yönelik bir araştırma. International Journal of Academic Value Studies, 3(8), 25-40. https://doi.org/10.23929/javs.88

Kalafat, T. (2012). Kariyer geleceği ölçeği (CFI): türk örneklemi için psikometrik özelliklerinin incelenmesi. Türk Psikolojik Danışma ve Rehberlik Dergisi, 4(38), 169-179.

Karadaş, A., Duran, S., \& Kaynak, S. (2017). Hemşirelik öğrencilerinin kariyer planlamaya yönelik görüşlerinin belirlenmesi. SDÜ Sağllk Bilimleri Enstitüsü Dergisi, 8(1), 1-8. https://doi.org/10.22312/sdusbed.224956

Kılıç, Y., Coşkuner, Z., \& Karakaya, Y. E. (2020). Spor bilimleri alanında eğitim alan öğrencilerin kariyer geleceklerine yönelik tutumları. Uluslararası Toplum Araştırmaları Dergisi, 15(23), 2064-2078. https://doi.org/10.26466/opus.666255

Kuzu, A. (2013). Araştırmaların Planlanması. In A. A. Kurt (Ed.), Bilimsel Araştırma Yöntemleri. Anadolu Üniversitesi Yayını, Eskişehir.

Özdemir, S. (2012). Ön lisans muhasebe öğrencilerinin kariyer planlamasını etkileyen unsurlar: Ege bölgesinde bir araştırma.

Özşen, Z. S. (2019). Turizm öğrencilerinin kariyer geleceği algılarını etkileyen etmenlerin incelenmesi. Turizm Çalışmaları Dergisi, 1(1), 43-53.

Serin, E., Soran, S., \& Kılıç, A.O. (2014). Üniversite öğrencilerinin kariyer değerlerinin eğitim süreleri açısından incelenmesi ve bir uygulama. C. Ü. Íktisadi ve İdari Bilimler Dergisi, 15(1), 209-220.

Şimşek, A. (2012). Evren ve Örneklem. In A. Şimşek (Ed.), Sosyal bilimlerde Araştırma Yöntemleri. Anadolu Üniversitesi Yayını, Eskişehir.

Taşlıyan, M., Arı, N. Ü., \& Duzman, B. (2011). insan kaynakları yönetiminde kariyer planlama ve kariyer yönetimi: Iibf öğrencileri üzerinde bir alan araştırması. Organizasyon Ve Yönetim Bilimleri Dergisi, 3(2), 231-241.

Temel, V., \& Nas, K. (2018). Beden eğitimi ve spor yüksekokulu öğrencilerinin kariyer geleceği algı düzeylerinin incelenmesi. İn̈nü Üniversitesi Beden Eğitimi ve Spor Bilimleri Dergisi, 5(3), 35-45.

Üzüm, B., \& Uçkun, S. (2015). Büro yönetimi ve yönetici asistanlığı öğrencilerinin demografik özellikleri ile kariyer geleceği beklentilerinin ölçülmesi: Kocaeli myo örneği. 
Elektronik Mesleki Gelişim ve Araştırmalar Dergisi, 3(1), 71-80.

Y1lmaz, İ. A., Dursun, B., Pektaş, K., \& Altay, A. (2012). Üniversite öğrencilerinin kariyer seçimlerinin demografik özellikler açısından incelenmesi: Pınarhisar myo örneği. Electronic Journal of Vocational Colleges.

\section{Copyright Disclaimer}

Copyright for this article is retained by the author(s), with first publication rights granted to the journal.

This is an open-access article distributed under the terms and conditions of the Creative Commons Attribution license (http://creativecommons.org/licenses/by/3.0/). 